\title{
A social work study on the effect of personal characteristics on academic performance
}

\author{
Maryam Mehri ${ }^{{ }^{*}}$, Fatemeh Rezaei ${ }^{\mathrm{b}}$ and Mohammad Reza Abedi ${ }^{\mathrm{c}}$
}

${ }^{a}$ MS Student, Counseling Department, Islamic Azad University of Khomeinishahr, Khomeinishahr Branch, Daneshjou Blvd, Iran

${ }^{b}$ Assistant Professor, Counseling Department, Islamic Azad University of Khomeinishahr,Khomeinishahr Branch, Daneshjou Blvd, Iran ${ }^{c}$ Associate Professor, Department of Counseling, University of Isfahan, Isfahan, Iran

\section{H R O N I C L E}

Article history:

Received December 2, 2012

Received in revised format

10 March 2013

Accepted 14 March 2013

Available online

March 142013

Keywords:

Career interest

Mental health

Happiness

Aptitude and Academic

performance

\section{A B S T R A C T}

\begin{abstract}
This study examines the relationship between career interests, aptitude, mental health, happiness and academic performance among first-year high school students. The proposed study performs a descriptive research on 370 first-year students using multistage random cluster survey to collect the necessary data. The proposed study also uses strong career interest questionnaires, Oxford Happiness test, Health and Aptitude test scores and the semester GPA scores. Research data are analyzed by Pearson correlation coefficient, and stepwise regression procedures. The results indicate that there is a significant and direct relationship between realistic, investigative, artistic, social, enterprising, convention and academic performance; but there is an unusual and significant inverse relation between realistic and academic performance. In addition, there is a direct relationship between mental health and academic performance, and between aptitude, happiness and academic performance. Generally, there is a relationship between career interest, aptitude, mental health, happiness and academic performance; and the greatest impact on academic performance is related to career interest, particularly investigative interest.
\end{abstract}

\section{Introduction}

One of the primary concerns on educational systems is to learn about the effect of various factors on improving academic performance and there are literally different studies associated with this issue (Hogan, 1976; Diener, 2006). Andrews and Wilding (2004), for instance, investigated the effects of depression and anxiety to life-stress and achievement in students. Acar (2011), for instance, investigated social capital's impacts on academic success in education by studying the definition of social capital. According to Diener and Diener (1996) some people were looking for finding happy people but just examined the level of happiness. In fact, most people report a positive level of subjective well-being (SWB), and believe that they were satisfied with domains such as marriage, work, and leisure.

Corresponding author. Tel: +989132022795

E-mail: maryam.mehri@iaukhsh.ac.ir (M. Mehri)

(C) 2013 Growing Science Ltd. All rights reserved. doi: 10.5267/j.msl.2013.03.015 
Lyubomirsky (2001) in another study studied why some people were happier than others and investigated the role of cognitive and motivational processes in well-being. Gil-Olarte Márquez et al. (2006) investigated the effect of emotional intelligence on social competence and academic achievement in high school students. Veenhoven and Choi (2012) studied whether intelligence could boost happiness and Smartness of all pays more than being smarter than others do. Deary et al. (2007) performed a 5-year prospective longitudinal investigation on 70,000 + English children and examined the association between psychometric intelligence at age 11 years and educational achievement in national examinations in 25 academic subjects at age 16. The correlation between a latent intelligence trait and a latent trait of educational achievement was reported as 0.81 and general intelligence contributed to success on all 25 subjects.

In this paper, we present an empirical study on the effects the various personal characteristics on academic performance. This paper is organized as follows. We first present details of the proposed study in section 2, section 3 presents the results of finally, concluding remarks are given in the last to summarize the contribution of the paper.

\section{The proposed study}

The population of this survey includes 21361 first year students who attended high schools in city of Esfahan, Iran during the fiscal year of 2011-2012 and the sample size is calculated as 377 students according to Morgan Table. The proposed study of this paper selects five out of six regions in this city and, using clustering technique, selects students, randomly. There are different questionnaires in this survey. The first part of survey uses strong career interest questionnaires, which includes 290 questions in six parts. Each question is categorized in terms of five categories of completely agree, agree, no comment, disagree and completely disagree.

The proposed study also uses strong career interest questionnaires, Oxford Happiness test, Health and Aptitude test scores and the semester GPA scores. Research data are analyzed by Pearson correlation coefficient, and stepwise regression procedures (Blackwell \& Case 2008; Donnay, 1997). Cronbach alpha for the questions in this part was generally greater than 0.80 .

\section{The results}

In this section, we present details of our survey on various hypotheses.

\subsection{First hypothesis: The relationship between educational performance and career interest}

The first hypothesis of this survey investigates whether there is any positive relationship between educational performance and career interest. Table 1 shows details of Pearson correlation ratios between these two items in different fields.

\section{Table 1}

The results of Pearson correlation ratio between educational background and career interest

\begin{tabular}{lcccccc}
\hline Performance & Realistic & Investigative & Artistic & Social & Enterprising & Convention \\
\hline Pearson ratio & -0.87 & 0.488 & 0.105 & 0.189 & 0.203 & 0.131 \\
P-value & $95 \%$ & 0.001 & 0.043 & 0.001 & 0.001 & 0.031 \\
Number & 370 & 370 & 370 & 370 & 370 & 370 \\
\hline
\end{tabular}

The results indicate that there is a significant and direct relationship between realistic, investigative, artistic, social, enterprising, convention and academic performance; but there is an unusual and significant inverse relation between realistic and academic performance. We have also performed multi-dimensional correlation and the results indicate that there is a meaningful relationship between 
career interest and academic performance with $\mathrm{r}=0.549(\mathrm{P}=0.001)$. Table 2 shows details of our findings in terms of ANOVA test.

Table 2

The results of ANOVA test

\begin{tabular}{lccccc}
\hline Source of change & Sum of Squares & df & Mean of Squares & F & P-Value \\
\hline Regression & 1116.65 & 6 & 186.11 & 26.04 & 0.001 \\
Residual & 2594.68 & 366 & 7.15 & & \\
\hline Total & 3711.33 & 369 & - & & \\
\hline
\end{tabular}

The results of Table 2 indicate that we can rely on linear regression technique to study the relationship between academic performance as independent variable and other independent variables. Table 3 demonstrates the results of step-wise regression results.

Table 3

The summary of step-wise regression analysis

\begin{tabular}{lccccc}
\hline & Value & Standard deviation & Standard beta & t-student & P-value \\
\hline Intercept & 10.876 & 0.820 & - & 13.270 & 0.001 \\
Investigative & 0.133 & 0.013 & 0.515 & 10.494 & 0.001 \\
Realistic & -0.080 & 0.014 & 0.278 & -5.553 & 0.001 \\
Enterprising & 0.036 & 0.018 & 0.109 & 2.017 & 0.001 \\
\hline
\end{tabular}

The results of t-student values in Table 3 are meaningful when the level significance is one percent. The values of beta indicate the relative effectiveness of different components.

\subsection{The second hypothesis: The relationship between academic performance and mental health}

The second hypothesis of this survey studies the relationship between academic performance and mental health among students who took part in our survey. The result of Pearson correlation ratio is equal to 0.217 with $p$-value $<0.001$, which means there is a positive and meaningful relationship between these factors. Table 4 shows details of our findings in terms of ANOVA test.

\section{Table 4}

The results of ANOVA test

\begin{tabular}{lccccc}
\hline Source of change & Sum of Squares & df & Mean of Squares & F & P-Value \\
\hline Regression & 109.252 & 1 & 109.252 & 11.685 & 0.001 \\
Residual & 2206.557 & 236 & 9.350 & & \\
\hline Total & 2315.808 & 337 & - & & \\
\hline
\end{tabular}

The results of Table 4 indicate that we can depend on linear regression analysis to investigate the relationship between academic performance as independent variable and mental health as dependent variable. Table 5 presents the results of step-wise regression results.

Table 5

The summary of step-wise regression analysis

\begin{tabular}{lccccc}
\hline & Value & Standard deviation & Standard beta & t-student & P-value \\
\hline Intercept & 7.292 & 0.247 & - & 3.245 & 0.001 \\
Mental health & 0.153 & 0.045 & 0.217 & 3.418 & 0.001 \\
\hline
\end{tabular}

The results of t-student values in Table 5 are meaningful when the level significance is one percent. The values of beta indicate the relative effectiveness of mental health. 


\subsection{The third hypothesis: The relationship between academic performance and aptitude}

The third hypothesis of this survey investigates the relationship between academic performance and aptitude among students who participated in our survey. Pearson correlation ratio has been calculated as 0.345 with p-value $<0.001$, which means there is a positive and meaningful relationship between these two factors and Table 6 presents details of ANOVA test.

\section{Table 6}

The results of ANOVA test

\begin{tabular}{lccccc}
\hline Source of change & Sum of Squares & df & Mean of Squares & F & P-Value \\
\hline Regression & 451.29 & 1 & 451.29 & 50.92 & 0.001 \\
Residual & 3332.68 & 376 & 8.86 & & \\
\hline Total & 3783.97 & 377 & - & & \\
\hline
\end{tabular}

The results of Table 6 indicate that there was a linear relationship between academic performance as independent variable and aptitude as dependent variable. Table 7 shows the results of step-wise regression results.

\section{Table 7}

The summary of step-wise regression analysis

\begin{tabular}{lccccc}
\hline & Value & Standard deviation & Standard beta & t-student & P-value \\
\hline Intercept & 11.148 & 0.639 & - & 17.44 & 0.001 \\
Aptitude & 0.044 & 0.006 & 345 & 7.14 & 0.001 \\
\hline
\end{tabular}

The results of t-student values in Table 7 are meaningful when the level significance is one percent. The values of beta indicate the relative effectiveness of aptitude.

\subsection{The fourth hypothesis: The relationship between academic performance and happiness}

The fourth hypothesis of this study looks for the relationship between academic performance and happiness among students who attended in our study. Pearson correlation ratio has been calculated as 0.116 with $\mathrm{p}$-value $<0.023$, which means there is a positive and meaningful relationship between these two factors when the level of significance is five percent and Table 8 presents details of ANOVA test.

\section{Table 8}

The results of ANOVA test

\begin{tabular}{lccccc}
\hline Source of change & Sum of Squares & df & Mean of Squares & F & P-Value \\
\hline Regression & 52.333 & 1 & 52.333 & 5.188 & 0.023 \\
Residual & 3853.590 & 382 & 10.088 & & \\
\hline Total & 3905.924 & 383 & - & & \\
\hline
\end{tabular}

The results of Table 8 indicate that there is a linear relationship between academic performance as independent variable and happiness as dependent variable. Table 9 shows the results of step-wise regression results.

\section{Table 9}

The summary of step-wise regression analysis

\begin{tabular}{lccccc}
\hline & Value & Standard deviation & Standard beta & t-student & P-value \\
\hline Intercept & 14.47 & 0.491 & - & 29.459 & 0.001 \\
Happiness & 0.022 & 0.010 & 0.116 & 2.278 & 0.23 \\
\hline
\end{tabular}

The results of t-student values in Table 9 are meaningful when the level significance is one percent. The values of beta indicate the relative effectiveness of aptitude. 


\subsection{The fifth hypothesis: The relationship between career interest, mental health, aptitude, happiness} and academic performance

Finally, we study the relationship between career interest, mental health, aptitude, happiness and academic performance. We first present details of our survey on Pearson correlation ratios among these components.

\section{Table 10}

The results of Pearson correlation ratios between career interest, mental health, aptitude, happiness and academic performance

\begin{tabular}{lccccccccc}
\hline Performance & Happiness & Realistic & Investigative & Artistic & Social & Enterprising & Convention & Aptitude & Mental health \\
\hline Pearson ratio & 0.116 & -0.87 & 0.488 & 0.105 & 0.189 & 0.203 & 0.131 & 0.345 \\
P-value & 0.023 & $95 \%$ & 0.001 & 0.043 & 0.001 & 0.001 & 0.031 & 0.001 \\
Number & 384 & 370 & 370 & 370 & 370 & 370 & 370 & 378 \\
\hline
\end{tabular}

The results of Table 10 show that except the case of "Realistic", there is a meaningful relationship between academic performance and happiness, being investigative, artistic, social, enterprising, convention, aptitude and mental health.

We have also performed multi-dimensional correlation and the results indicate that there is a meaningful relationship between career interest and academic performance with $\mathrm{r}=0.58(\mathrm{P}=0.001)$. Table 11 shows details of our findings in terms of ANOVA test.

\section{Table 11}

The results of ANOVA test

\begin{tabular}{lccccc}
\hline Source of change & Sum of Squares & df & Mean of Squares & F & P-Value \\
\hline Regression & 700.492 & 9 & 77.832 & 11.817 & 0.001 \\
Residual & 1382.117 & 210 & 6.586 & & \\
\hline Total & 3711.33 & 219 & - & & \\
\hline
\end{tabular}

The results of Table 11 indicate that we can rely on linear regression technique to study the relationship between academic performance as independent variable and other independent variables. Table 12 demonstrates the results of step-wise regression results.

\section{Table 12}

The summary of step-wise regression analysis between academic performance and investigative, aptitude and realistic

\begin{tabular}{lccccc}
\hline & Value & Standard deviation & Standard beta & t-student & P-value \\
\hline Intercept & 9.052 & 1.054 & - & 8.588 & 0.001 \\
Investigative & 0.119 & 0.014 & 0.500 & 8.240 & 0.001 \\
Aptitude & 0.026 & 0.007 & 0.220 & 3.814 & 0.001 \\
Realistic & -0.054 & 0.016 & -0.199 & -3.356 & 0.001 \\
\hline
\end{tabular}

The results of Table 12 show that being investigative has the most positive influence on academic performance followed by aptitude but being realistic has negative relationship with academic performance.

To answer the main question of the survey, we are interested in learning the effects of each independent variable on academic performance for the proposed study of this paper. Table 13 summarizes the results of our survey on performing regression analysis.

The results of Table 13 show that only a few variables maintain significant effects on academic performance. 
Table 13

The results of regression analysis

\begin{tabular}{lccccc}
\hline & Value & Standard deviation & Standard beta & t-student & P-value \\
\hline Intercept & 9.437 & 2.455 & - & 3.844 & 0.001 \\
Being investigative & 0.116 & 0.018 & 0.487 & -429 & 0.001 \\
Being realistic & -0.63 & 0.019 & -0.232 & -3.386 & 0.001 \\
Aptitude & 0.027 & 0.007 & 0.224 & 3.819 & 0.001 \\
Being social & 0.048 & 0.24 & 0.149 & 2.032 & 0.043 \\
Being Artistic & 0.021 & 0.024 & 0.056 & 0.869 & 0.386 \\
Mental health & 0.020 & 0.024 & 0.029 & 0.437 & 0.663 \\
Convention & 0.007 & 0.023 & 0.022 & 0.291 & 0.771 \\
Happiness & 0.002 & 0.011 & 0.010 & 0.0165 & 0.869 \\
Enterprising & 0.001 & 0.026 & 0.002 & 0.030 & 0.976 \\
\hline
\end{tabular}

\section{Conclusion}

In this survey, we have performed an empirical study to find the effects of various factors on academic performance using Pearson correlation ratio as well as step-wise regression analysis. The results of our survey have indicated that there was a meaningful relationship between career interest and academic performance, between academic performance and mental health, between academic performance and happiness and between career interest, mental health, aptitude, happiness and academic performance.

\section{References}

Acar, E. (2011). Effects of social capital on academic success: A narrative synthesis. Educational Resource Review, 6, 456-461.

Andrews, B., \& Wilding, J. M. (2004). The relation of depression and anxiety to life-stress and achievement in students. British Journal of Psychology, 95(4), 509-521.

Blackwell, T., \& Case, J. (2008). Strong interest inventory. Rehabilitation Counseling Bulletin, 51 (2), 122-126.

Deary, I. J., Strand, S., Smith, P., \& Fernandes, C. (2007). Intelligence and educational achievement. Intelligence, 35(1), 13-21.

Diener, E., \& Diener, C. (1996). Most people are happy. Psychological science,7(3), 181-185.

Diener, E. (2006). Guidelines for national indicators of subjective well-being and ill-being. Applied Research in Quality of Life, 1(2), 151-157.

Donnay, D. (1997). E.K. Strong's legacy and beyond: 70 years of the strong interest inventory. Career Development Quarterly, 46 (1), 2-22.

Gil-Olarte Márquez, P., Palomera Martín, R., \& Brackett, M. A. (2006). Relating emotional intelligence to social competence and academic achievement in high school students. Psicothema, 18, 118-123.

Lyubomirsky, S. (2001). Why are some people happier than others? The role of cognitive and motivational processes in well-being. American Psychologist,56(3), 239.

Hogan, R. (1976). Personality theory perso logical tradition. Prentice - hall. Englewood cliffs, New Jersey.

Veenhoven, R., \& Choi, Y. (2012). Does intelligence boost happiness? Smartness of all pays more than being smarter than others. International Journal of Happiness and Development, 1(1), 5-27. 